Chirurgia (2018) 113: 534-541

No. 4, July - August

Copyright@ Celsius

http://dx.doi.org/10.21614/chirurgia.113.4.534

\title{
The Role of Beta-7 Integrin and Carbonic Anhydrase IX in Predicting the Occurrence of de Novo Nonalcoholic Fatty Liver Disease in Liver Transplant Recipients
}

\author{
Carmen Ester', Razvan Cerban', Speranta lacob', Corina Pietrareanu', Georgiana Constantin², Liliana Paslaru², \\ Simona Ichim ${ }^{1}$, Mihaela Lita', Roxana Vadan', Camelia Grancea ${ }^{3}$, Simona Ruta ${ }^{3}$, Cristian Gheorghe ${ }^{1}$, Irinel Popescu ${ }^{4}$, \\ Liana Gheorghe ${ }^{1}$
}

'Department of Hepatology and Liver Transplantation, Fundeni Clinical Institute, Bucharest, Romania ${ }^{2}$ Department of Biochemistry - Liver Transplant Unit, Fundeni Clinical Institute, Bucharest, Romania ${ }^{3}$ Stefan Nicolau Virology National Institute, Bucharest, Romania

${ }^{4}$ General Sugery Department - Liver Transplant Unit, Fundeni Clinical Institute, Bucharest, Romania

Corresponding author:

Liana Gheorghe, MD, PhD

Department of Gastroenterology

and Hepatology, Fundeni Clinical

Institute, Bucharest, Romania

E-mail: drlgheorghe@gmail.com

\section{Rezumat}

Rolul integrinei Beta-7 și al anhidrazei carbonice IX în predicția aparitiei steatozei hepatice și complicațiilor ei de novo la pacienții transplantati hepatic

Introducere: Pacienții transplantați hepatic prezintă un risc crescut de apariție a sindromului metabolic. Detectarea precoce a NAFLD şi a altor componente ale sindromului metabolic este un pas important în reducerea morbidității şi mortalității.

Metode: Am evaluat 60 de pacienți transplantati hepatic prin caracteristici clinice şi biologice, am efectuat ecografie abdominala şi elastografie - Fibroscan ${ }^{\circledR}$ cu parametru controlat de atenuare (CAP), am calculate scoruri non-invazive: APRI, FIB-4, NAFLD, riscul cardiovascular (scorul Framingham) şi pentru prezența sindromului metabolic şi am evaluat 2 biomakeri: integrina beta 7 şi anhidraza corbonica IX.

Rezultate: Vârsta medie a fost de 56,5 ani, iar timpul median de la transplant a fost de 35 de luni. Coeficientul de corelare Spearman al integrinei beta 7 şi rigiditatea hepatica obținute prin Fibroscan ${ }^{\circledR}$ a rezultat într-o corelație moderată $r=0,31$, dar o asociere semnificativă $(p=0,01)$. Analiza univariată a evidentiat o asociere semnificativă între biomarkeri şi fibroza hepatică cu un cut-off pentru fibroza avansată de $8,7 \mathrm{kPa}$. Anhidraza carbonică IX a prezentat o corelație mai bună comparativ cu rigiditatea hepatică 
cu un coeficient de corelație de 0,43 şi o valoare $p=0,0007$ şi o corelație moderată în comparație cu scorul FIB-4 $(r=0,27)$ şi APRI $(r=0,27)$ pentru fibroza hepatică, dar cu o valoare $\mathrm{p}$ semnificativă $=$ 0,04 , respectiv 0,03 .

Concluzii: Considerăm foarte important pentru pacienții noştri dezvoltarea de noi biomarkeri noninvazivi pentru diagnosticarea precoce a NAFLD şi NASH, deoarece "standardul de aur" al biopsiei hepatice nu este uşor acceptat în practica clinică. De asemenea, NAFLD şi NASH sunt procese dinamice care necesită evaluări prospective şi repetate, o necesitate care nu poate fi satisfăcută de biopsia hepatică.

Cuvinte cheie: steatoza hepatica post transplant hepatic, diagnostic non-invaziv, diagnostic precoce

\section{Abstract}

Background: Liver transplant (LT) recipients are at increased risk for developing metabolic syndrome. Early detection of NAFLD and other components of the metabolic syndrome is an important step in reducing morbidity and mortality.

Methods: We assessed 60 liver transplant recipients for clinical and biological features, performed abdominal ultrasound and transient elastography (TE) Fibroscan ${ }^{\circledR}$ with controlled attenuation parameter (CAP), calculated non-invasive scoring systems APRI, FIB-4, NAFLD score, cardiovascular risk (Framingham risk score) and for the presence of metabolic syndrome and performed two biomarkers: beta 7 integrin and carbonic anhydrase IX.

Results: Sixty liver transplant recipients underwent clinical and biochemical evaluation, abdominal ultrasound and TE with CAP. The median age was 56.5 years and the median time from transplantation 35 months. The Spearman correlation coefficient of beta 7 integrin and the liver stiffness measurement values obtained via Fibroscan ${ }^{\circledR}$ we obtained a moderate correlation $r=0.31$, but a significant association $(\mathrm{p}=0.01)$. The univariate analysis showed significant association between both biomarkers and liver fibrosis assessed with a cut-off value of advanced fibrosis of $8.7 \mathrm{kPa}$. The carbonic anhydrase IX showed a better correlation when compared to the liver stiffness with a correlation coefficient of 0.43 and $\mathrm{p}$-value $=0.0007$ and a moderate correlation when compared to both FIB-4 $(r=0.27)$ and APRI ( $r=0.27)$ score for liver fibrosis but with a significant $\mathrm{p}$ value $=0.04$, respectively 0.03 .

Conclusion: We consider very important for our patients the development of new non-invasive biomarkers for early diagnosis of NAFLD and NASH, as the "gold-standard" of liver biopsy is not easily accepted in clinical practice. Also NAFLD and NASH are dynamic processes that need prospective and repeated assessments, a need that cannot be met by the classical liver biopsy.

Key words: non-alcoholic fatty liver disease, non-invasive diagnosis, early detection

\section{Introduction}

De novo nonalcoholic fatty liver disease (NAFLD) in liver transplanted patients for cirrhosis not due to nonalcoholic steatohepatitis is becoming a growing phenomenon.

Liver transplant (LT) recipients are at increased risk for developing metabolic syndrome, partly due to immunosuppressive therapy, but also to changes in lifestyle and diet which suddenly becomes less restrictive in the post-transplant setting.

Non-alcoholic fatty liver disease is considered the hepatic phenotype of metabolic syndrome and its steady rate of progression from steatosis to non-alcoholic steatohepatitis (NASH), liver cirrhosis and hepatocellular carcinoma is well known. 
Early detection of NAFLD and other components of the metabolic syndrome is an important step in reducing morbidity and mortality in high risk populations, such as liver transplant recipients.

It is known that patients with NAFLD have a higher liver related mortality than patients without NAFLD, and also that fibrosis stage is the main predictor for hepatic outcome, thus initiating the search for triggers of fibrogenesis. The necroinflammation associated to NAFLD and NASH could be the main trigger, but biomarker based necro-inflammatory scores and their dynamic change also play a key role as proven by biopsy guided studies (1).

Biomarkers are widely acceptable in the general population as a screening and diagnostic method and unlike the gold standard of liver biopsy they can be used in the follow-up of these patients.

One recent study comprising a large cohort of biopsy proven NAFLD patients showed that the severity of the liver disease increases with the progression of fibrosis but not with the presence of NASH (2).

Disease progression is an important concern as we can observe a rapid progression of fibrosis, being doubled by the presence of arterial hypertension (3).

The occurrence of hepatocellular carcinoma associated to NAFLD/cryptogenic cirrhosis is considered to be 10 times higher in patients with type 2 diabetes mellitus and obesity(4).

Serum biomarkers for detecting fibrosis and steatosis may have a key role in the follow up of liver transplant recipients especially as we are facing a dynamic process for which liver biopsy is neither the safest nor the most easily acceptable test for the patients.

APRI, FIB-4 and NAFLD fibrosis scores, all based on serum biomarkers, have already been validated as tools for measuring fibrosis in liver transplant recipients with good AUROCs in predicting mortality, liver related mortality and graft loss (5), and they can change acutely with the onset of liver complications.

In LT recipients a study by Crespo et al. clearly demonstrated the usefulness of liver stiffness measurement by Fibroscan ${ }^{\circledR}$ at 1 year after liver transplantation to determine clinical prognosis using a cut-off of 8.7 kilopas- $^{-}$ cals $(\mathrm{kPa})$ in order to stratify patients with low LSM that can be confidently managed without liver biopsy and patients with high LSM that are at increased risk for graft loss (6).

As inflammation is the precursor of liver fibrosis we should aim to diagnose and control inflammation in order to prevent or early diagnose the onset of fibrosis. Histologically inflammation is characterized by accumulation of leucocytes in the affected tissue and there are three factors that control this process: the leucocytes, the cytokines leucocytes produce and the vascular endothelium.

Integrins are adhesion molecules located on leucocytes, being involved in the rolling process but also on the arrest onto the endothelial cells. Integrin beta 7 has been cited to be associated with steatohepatitis initiation and fibrosis progression in animal studies (7).

Carbonic anhydrase belongs to a large family of metalloenzymes involved at a cellular level in the process of $\mathrm{pH}$ regulation, biosynthetic reactions and tumorigenesis. Carbonic anhydrase IX (CAIX) is considered an antitumor target for renal cell carcinoma as a widely expressed gene in response to hypoxia.

The objectives of our study were to evaluate the use of beta 7 integrin and carbonic anhydrase IX as biomarkers for early detection of fibrosis in liver transplant recipients, acknowledging the results of the studies that differentiate between the outcome of LT recipients according to the degree of fibrosis (8).

\section{Materials and Methods}

We assessed 60 liver transplant recipients for clinical and biological features, performed abdominal ultrasound and transient elastography (TE) Fibroscan ${ }^{\circledR}$ with controlled attenuation parameter (CAP), calculated noninvasive scoring systems for advanced fibrosis and NAFLD (APRI, FIB-4, NAFLD score), for cardiovascular risk (Framingham risk score) and for the presence of metabolic syndrome.

Most of the patients (69\%) were transplanted for HCV liver cirrhosis and only $15 \%$ for 
$\mathrm{HBV}+\mathrm{HDV}$ liver cirrhosis. All of the HCV transplanted patients had recurrence of $\mathrm{HCV}$ infection shortly after liver transplantation (36 months), but the availability of direct acting antivirals helped treating these patients in mild degrees of fibrosis.

The presence of metabolic syndrome was assessed using the American Heart Association criteria that requires 3 or more of the following in order to make the diagnosis: abdominal obesity, high triglycerides (TG) or on TG lowering therapy, low HDL cholesterol, high blood pressure, elevated fasting glucose/on glucose lowering therapy.

\section{Statistical Analysis}

Analysis was performed in order to search for correlations between the serum level of beta 7 integrin and carbonic anhydrase IX with liver stiffness measurement by TE (using a cut-off of $8.7 \mathrm{kPa}$ ), CAP for significant steatosis (using a cutoff of $280 \mathrm{db} / \mathrm{m}$ ) and serum biomarkers already included in validated prediction models for fibrosis and inflammation.

Uni and multivariate analysis by stepwise regression analysis were performed and we also applied the Spearman correlation coefficient test. A p-value less than 0.05 was considered significant for all tests.

\section{Results}

Sixty liver transplant recipients were included in the study. All patients underwent clinical and biochemical evaluation, abdominal ultrasound and TE with CAP. The median age was 56.5 years and the median time from transplantation 35 months (Fig. 1).

Thirty-six patients $(60 \%)$ were overweight $(\mathrm{BMI}>25 \mathrm{~kg} / \mathrm{sqm}), 14(23 \%)$ obese $(\mathrm{BMI}>30$ $\mathrm{kg} / \mathrm{sqm}) .76 \%$ of patients received tacrolimusbased immunosuppression following liver transplantation.

TE (Fibroscan $\left.{ }^{\circledR}\right)$ with CAP was performed in all patients: 16 patients $(26 \%)$ had advanced fibrosis (F3, F4) and the median value for CAP was $271 \mathrm{db} / \mathrm{m}$ (Figs. 2, 3).

The presence of metabolic syndrome in our

\section{Ethiologies for liver transplantation}

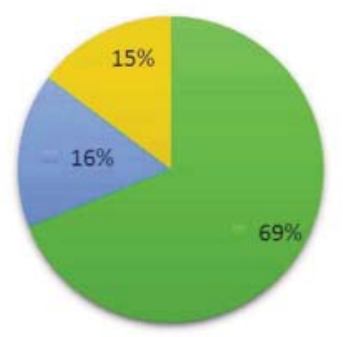

m $\mathrm{HCV}=\mathrm{HBV}+\mathrm{HDV}$ = Others

Figure 1. Causes of end-stage liver disease leading to liver transplantation

\section{Liver stiffness measurement (Fibroscan $^{\circledR}$ )}

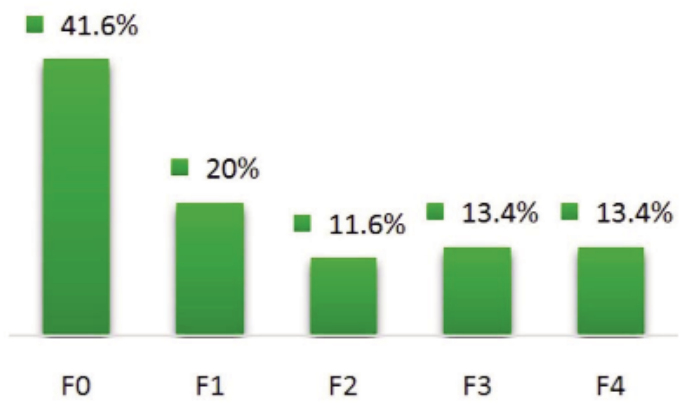

Figure 2. LSM interpreted as degree of fibrosis

\section{Liver steatosis \\ (CAP values)}

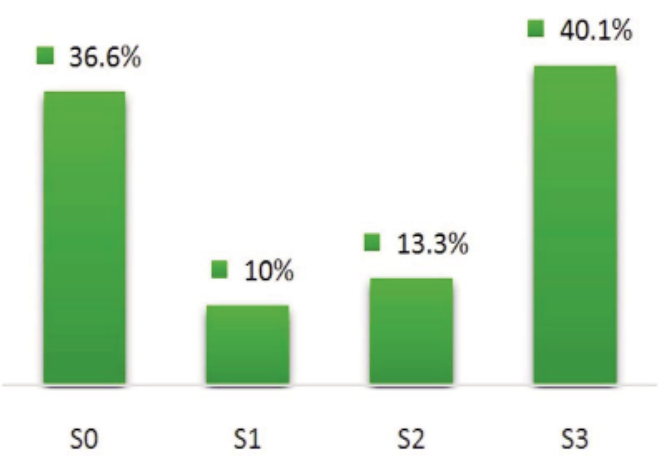

Figure 3. Liver steatosis according to CAP values 
study population was encountered in 52\% (32 patients).

The frequency of type 2 diabetes mellitus in the studied population was $60 \%$ (36 patients) and 12 patients $(20 \%)$ were diagnosed with new onset type 2 diabetes mellitus after liver transplantation. Regarding arterial hypertension the situation was similar with 30 patients being diagnosed with high blood pressure after liver transplantation, with a higher rate of new onset arterial hypertension of 32\% (19 patients)

The Framingham risk score for cardiovascular mortality was calculated in all patients as a gender specific algorithm used to estimate the 10 years cardiovascular risk of an individual. In

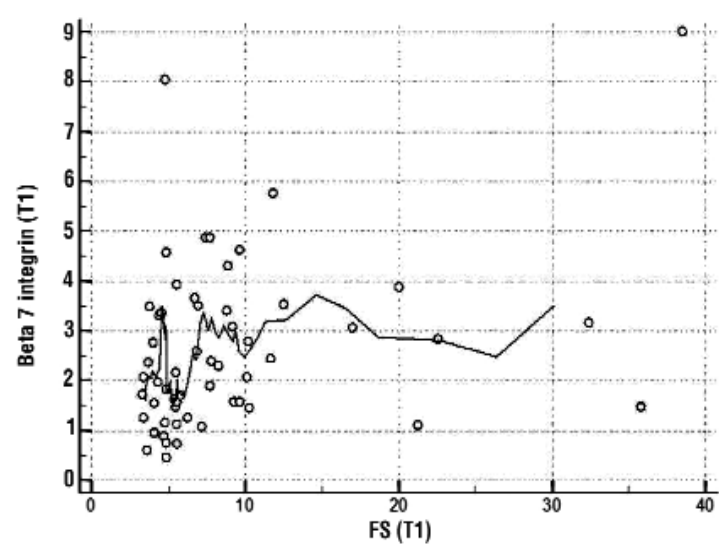

Figure 4. Spearman correlation - beta -7 integrin and liver stiffnes

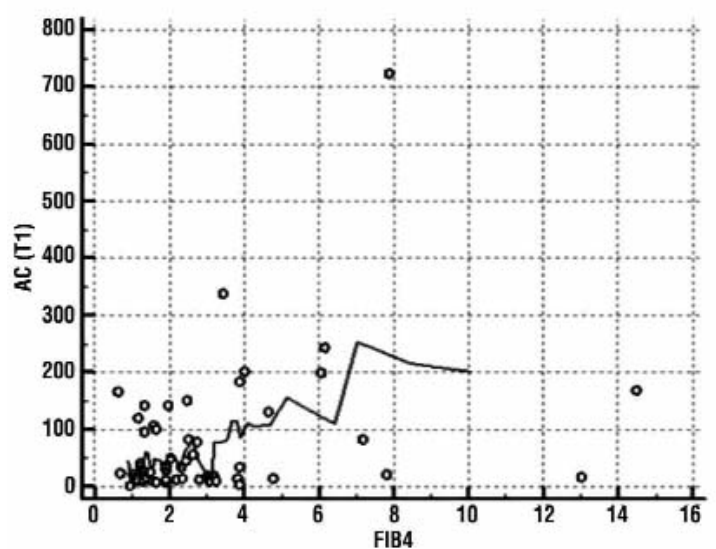

Figure 6. Spearman correlation of CAIX with FiB-4 score our study $13 \%$ of the patients were assessed to have a high cardiovascular risk at 10 years (2\%/year).

$\beta 7$-integrin serum concentration was performed for all patients and the mean value was $2.07 \mathrm{ng} / \mathrm{ml}$. Carbonic anhydrase IX was also performed with a mean value of 116 $\mathrm{pg} / \mathrm{ml}$.

When analyzing the Spearman correlation coefficient of beta 7 integrin and the liver stiffness measurement values obtained via Fibroscan ${ }^{\circledR}$ we obtained a moderate correlation $r=0.31$, but a significant association $(p=0.01)$ (Figs. 4-7).

The univariate analysis showed significant association between both biomarkers and liver

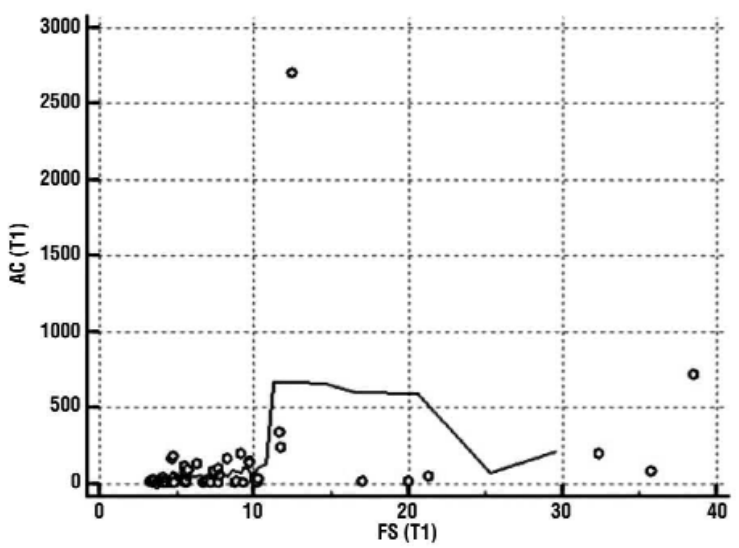

Figure 5. Spearman correlation of CAIX with liver stiffness measument values (Fibroscan®)

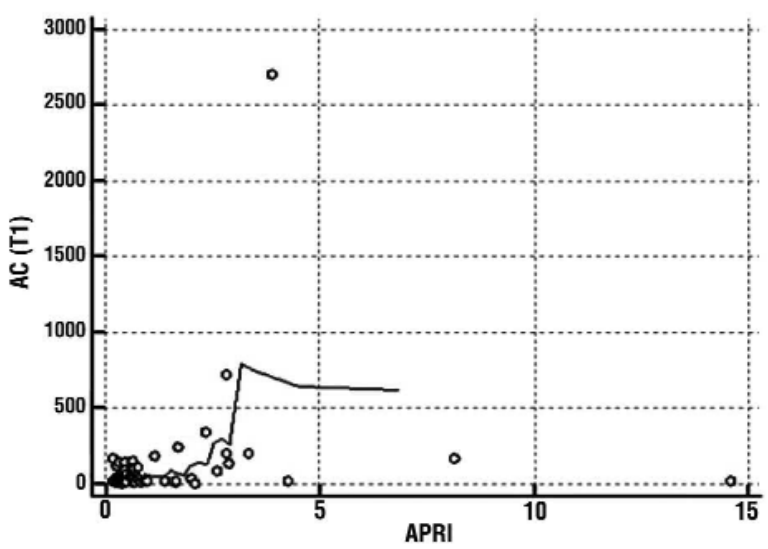

Figure 7. Spearman correlation of CAIX with the APRI score 
Table 1. Results of univariate analysis - Factors associated with advanced fibrosis after LT

\begin{tabular}{lrrr}
\hline Variable & LS $>\mathbf{8 . 7 k P a}(\mathbf{n}=\mathbf{1 9})$ & LS $<8.7 \mathbf{k P a}(\mathbf{n}=\mathbf{4 1})$ & $\mathbf{P}$ value \\
\hline CAIX $(\mathrm{pg} / \mathrm{ml})$ & 65.5 & 21.2 & 0.01 \\
\hline Beta-7 integrin $(\mathrm{ng} / \mathrm{ml})$ & 3.04 & 1.82 & 0.02 \\
\hline PLT/mm3 & 124000 & 164500 & 0.03 \\
\hline AST $(\mathrm{IU} / \mathrm{L})$ & 44 & 28 & 0.04 \\
\hline GGT $(\mathrm{IU} / \mathrm{L})$ & 84 & 34 & 0.09 \\
\hline CAP $(\mathrm{dB} / \mathrm{m})$ & 188 & 286 & 0.009 \\
\hline
\end{tabular}

fibrosis assessed with a cut-off value of advanced fibrosis of $8.7 \mathrm{kPa}$, but also some of the biochemical parameters of each patient (platelets, AST, GGT). The measurement of liver steatosis using CAP also showed a significant association when compared to the same cut-off for liver fibrosis (Table 1).

The multiple regression analysis was performed and the serum level of CAIX and CAP values were identified as independent risk factors for advanced fibrosis (Table 2).

All the non-invasive scores for liver fibrosis calculated for our patients were significantly higher in patients with advanced fibrosis on

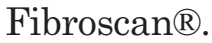

The carbonic anhydrase IX showed a better correlation when compared to the liver stiffness with a correlation coefficient of 0.43 and $p^{\text {-value }}=0.0007$ and a moderate correlation when compared to both FIB-4 $(\mathrm{r}=0.27)$ and APRI ( $r=0.27)$ score for liver fibrosis but with a significant $\mathrm{p}$ value $=0.04$, respectively 0.03 (Table 3).

\section{Discussion}

The prevalence of NAFLD is $20-30 \%$ and expected to increase worldwide. Liver transplant recipients are at higher risk of developing NAFLD because of the changes in lifestyle and the contribution of the immunosupression.

Recent studies have shown the impact of de novo NAFLD and NASH on cardiovascular disease and de-novo extrahepatic malignancies, all resulting in a 5 -fold higher risk of death (9).

Chronic inflammation within liver cells leads to the constitution of liver fibrosis as a result of accelerated matrix generation and impaired
Table 2. Results of multiple regression analysis

\begin{tabular}{lrr}
\hline Variable & Multiple correlation coefficient & P value \\
\hline CAIX $(\mathrm{pg} / \mathrm{ml})$ & 2.29 & 0.02 \\
\hline CAP $(\mathrm{dB} / \mathrm{m})$ & -2.53 & 0.01 \\
\hline
\end{tabular}

Table 3. Noninvasive serological scores of assessing fibrosis according to liver stiffness measurement

\begin{tabular}{lrrr}
\hline Variable & $\begin{array}{r}\text { LS }>\mathbf{8 . 7 k P a} \\
(\mathbf{n}=\mathbf{1 9})\end{array}$ & $\begin{array}{r}\text { LS }<\mathbf{8 . 7 k P a} \\
(\mathbf{n}=\mathbf{4 1 )}\end{array}$ & P value \\
\hline APRI & 1.05 & 0.5 & 0.01 \\
\hline FIB4 & 3.2 & 1.9 & 0.02 \\
\hline NAFLD & -1.6 & -2.1 & 0.03 \\
\hline
\end{tabular}

degradation. Integrins represent a family of transmembrane cellular protein receptors and their role is to mediate interactions between cells and the surrounding extracellular matrix.

Immune active cells contribute to the pathogenesis of liver diseases. $\alpha 4 \beta 7$ is an already known integrin to play an important role in lymphocyte trafficking in the GI tract via interaction with mucosal addressin cell adhesion molecule (MAdCAM). It has been shown that the process of immune cell recruitment and disease progression can be influenced by the pair MAdCAM-1/ $\beta 7$-integrin with $\beta 7$-integrin deficiency resulting in increased steatohepatitis.

Beta-7 integrin was shown in a recent animal model to have protective effects against the development of steatohepatitis, as beta 7 depleted mice showed earlier steatohepatitis initiation and significantly increased fibrosis progression (10).

Carbonic anhydrase IX is a marker of hypoxia and its expression was reportedly associated with 
poor prognosis in many cancers. It is a known fact that hypoxia and inflammation are interrelated at a molecular, cellular and clinical level. Just as hypoxia can induce inflammation, inflamed lesions often become severely hypoxic. Contributors to tissue hypoxia during inflammation are the high metabolic demands of cells and a reduction in metabolic substrates.

NAFLD fibrosis score is used on a large scale to assess the severity of liver fibrosis with high levels of sensitivity and specificity for ruling out $(<-1.45)$ and ruling in advanced fibrosis (>-0.67), thus diminishing the need to perform a liver biopsy.

FIB-4 index is based on a simpler formula but is also very good for distinguishing advanced fibrosis (>3.25). Recent studies have shown both the NAFLD fibrosis score and the FIB-4 index were as good as MR elastography in predicting advanced fibrosis $(11,12)$.

These blood-based prediction scores for liver fibrosis have not been initially developed for liver transplant recipients but they proved to be useful and later validated in post-transplant setting. A good association with the liver stiffness measurement by Fibroscan ${ }^{\circledR}$ was later observed, also a validated tool for liver transplant recipients, similar to our study (8).

Our study demonstrated that the serum levels of CAIX can be used as an independent risk factor for predicting advanced fibrosis in liver transplant recipients with a positive statistical correlation both with the liver stiffness values and the non-invasive prediction models for advanced fibrosis.

This is the first study to demonstrate the usefulness of the serum levels of CAIX and beta 7 integrin as biomarkers for moderate and advanced fibrosis in NAFLD in general but especially in liver transplant recipients in a moment when most experts suggest the need for developing new blood based biomarkers for this world wide growing epidemics in order to be able to early diagnose and prevent complications and comorbidities.

Demonstrating this in a high-risk population for NAFLD/NASH could be a key factor for the improvement of non-invasive diagnosis and further research should be developed.
The metabolic syndrome consists of a multitude of risk factors that increase the risk to develop cardiovascular disease in the future. In LT recipients, the prevalence of cardiovascular risk factors, such as obesity, diabetes and dyslipidemia, is increased compared to the general population, as shown by our study.

The cardiovascular risk is considered to be the main concern in the NALFD-NASHadvanced fibrosis evolution and our cohort showed an increased risk for cardiovascular mortality when assessed by the Framingham risk score. A recent study by Tsai et al. (13) identified in a large population-based survey a nine-fold increased risk in liver transplant recipients for developing cardiovascular complications in the post-transplant setting.

The lack of correlation to our biomarkers shows the need to do further research in this direction, and our study will continue including patients in order to have a more significant cohort.

\section{Conclusion}

The burden of NAFLD and metabolic syndrome in liver transplant recipients is very high, impacting on lifestyle and severely affecting morbidity and mortality in these patients. We consider very important for our patients the development of new non-invasive biomarkers for early diagnosis of NAFLD and NASH, as the "gold-standard" of liver biopsy is not easily accepted in clinical practice. Also NAFLD and NASH are dynamic processes that need prospective and repeated assessments, a need that cannot be met by the classical liver biopsy.

\section{Conflicts of Interest}

No conflict of interest.

\section{References}

1. Ratziu V. Back to Byzance: Querelles byzantines over NASH and fibrosis. J Hepatol. 2017;67(6):1134-1136.

2. Hagström H, Nasr P, Ekstedt M, Hammar U, Stțl P, Hultcrantz R, et al. Fibrosis stage but not NASH predicts mortality and time to development of severe liver disease in biopsy-proven NAFLD. J Hepatol. 2017:67(6):1265-1273.

3. Singh S, Allen AM, Wang Z, Prokop LJ, Murad MH, Loomba R. 
Fibrosis progression in nonalcoholic fatty liver vs nonalcoholic steatohepatitis: a systematic review and meta-analysis of pairedbiopsy studies. Clin Gastroenterol Hepatol. 2015;13(4):643-54.e19; quiz e39-40.

4. Dyson J, Jaques B, Chattopadyhay D, Lochan R, Graham J, Das D, et al. Hepatocellular cancer: the impact of obesity, type 2 diabetes and a multidisciplinary team. J Hepatol. 2014;60(1):110-7.

5. Bhat M, Ghali P, Rollet-Kurhajec KC, Bhat A, Wong P, Deschenes M, et al. Serum fibrosis biomarkers predict death and graft loss in liver transplant recipients. Liver Transpl. 2015;21(11):1383-94.

6. Crespo G, Lens S, Gambato M, Carrión JA, Mariño Z, Londoño MC, et al. Liver stiffness 1 year after liver transplantation predicts clinical outcomes in patients with recurrent hepatitis C. Am J Transplant. 2014;14(2):375-83.

7. Imajo K, Kessoku T, Honda Y, Tomeno W, Ogawa Y, Mawatari H, et al. Magnetic Resonance Imaging More Accurately Classifies Steatosis and Fibrosis in Patients With Nonalcoholic Fatty Liver Disease Than Transient Elastography. Gastroenterology. 2016; 150(3):626-637.e7.

8. Barrault C, Roudot-Thoraval F, Tran Van Nhieu J, Atanasiu C, Kluger MD, Medkour F, et al. Non-inasive assessment of liver graft fibrosis by transient elastography after liver transplanatation. Clin Res Hepatol Gastroenterol. 2013; 37(4):347-52.

9. Drescher HK, Schippers A, Clahsen T, Sahin H, Noels H, Hornef M, et al. $\beta 7$-Integrin and MAdCAM-1 play opposing roles during the development of non-alcoholic steatohepatitis. J Hepatol. 2017; 66(6):1251-1264.

10. Tapper EB, Krajewski K, Lai M, Challies T, Kane R, Afdhal N, et al. Simple non-invasive biomarkers of advanced fibrosis in the evcaluation of non-alcoholic fatty liver disease. Gastroenterol Rep (0xf). 2014; 2(4):276-80.

11. Drescher HK, Schippers A, Clahsen T, Sahin H, Noels H, Hornef M, et al. $\beta 7$-integrin and MadCAM-1 play opposing roles during the development of non-alcoholic steatohepatitis. J Hepatol. 2017; 66(6):1251-1264.

12. Gitto $\mathrm{S}$, Benedetto ED, et al De novo non-alcoholic steatohepatitis is associated with a five fold long-term increased mortality in liver transplant recipients. J. Hepatol. 2017;669(1, Suppl):S41.

13. Tsai HI, Liu FC, Lee CW, Kuo CF, See LC, Chung TT, et al Cardiovascular disease risk in patients receiving organ transplantation: a national cohort study. Transpl Int. 2017;30(11): 1161-1171. 